\title{
OBITUARY AND DEDICATION
}

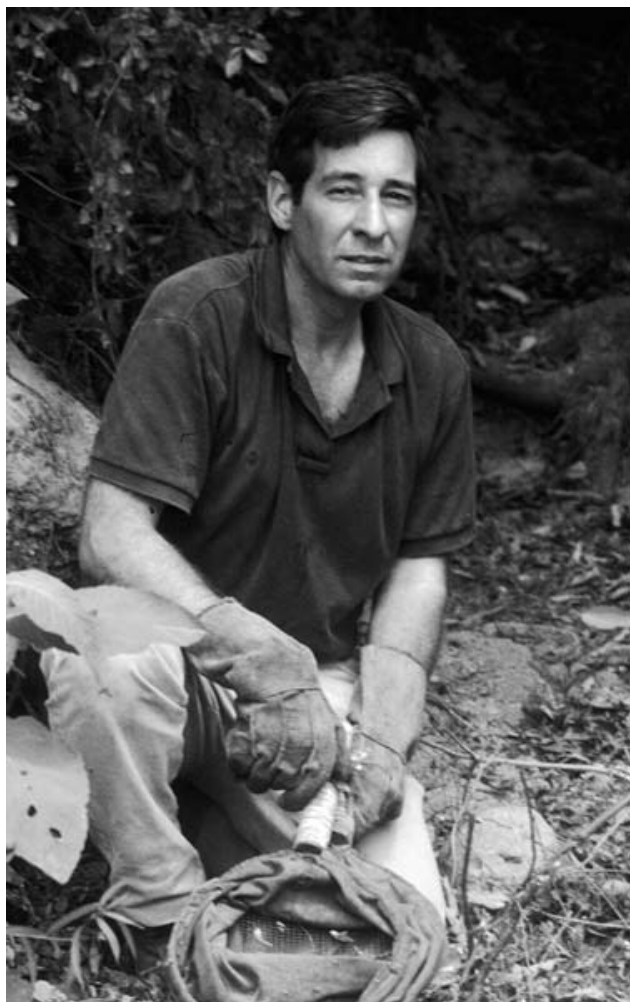

Steve Ashe sifting in Chiapas, Mexico, 1991 (Photo by Mary Liz Jameson).

\section{In Memoriam, James Stephen "Steve" Ashe}

\section{(1947-2005)}

Our esteemed coleopterist colleague, Steve Ashe, died December 27, 2005, just days after attending the annual Entomological Society of America meeting in Fort Lauderale, Florida and interacting with hundreds of other Coleopterists. Steve's sudden death at the early age of 58 is tragic, not only for the personal loss to his friends and family, but due to the scientific impact of his loss as well.

After receiving his Ph.D. under the mentorship of George Ball at the University of Alberta, Steve became curator at the Field Museum of Natural History in Chicago in 1982. Steve worked there for six years, eventually becoming head of the Division of Insects, and brought in substantial resources to expand and develop the entomological collections. Steve arranged for the acquisition of the Luis Peña collection of South American (especially Chilean) Coleoptera. This collection contained ober 170,000 pinned and papered specimens, including over 200 holotypes. Steve was the lead principal investigator of a large National Science Foundation collections enhancement grant that allowed, among other things, to begin databasing the Field Museum 
entomological collection. Steve then took a position in 1988 as Associate Professor and Director of the Snow Entomological Museum at the University of Kansas in Lawrence, a move precipitated in large part by his desire to become more involved in the education and training of students. In 1994, Steve was promoted to Chief Curator, Division of Entomology, Museum of Natural History and Biodiversity Research Center and Professor of Ecology and Evolutionary Biology at University of Kansas where he worked until his death.

While at the University of Kansas, Steve became one of the most influential and significant coleopterists of his generation and became a role model for everyone with his professional, ethical, and compassionate nature. He was the primary advisor of 11 students who received Ph.D. degrees (K.-J. Ahn, S. Chatzimanolis, J. Danoff-Burg, Z. Falin, R. Hanley, M. Jameson, C. Labandeira, R. Leschen, S. Lingafelter, G. Makranczy, and A. Slater) and 3 students who received M.Sc. degrees (M. Branham, C. Chaboo, and M. Gray) since 1989. Steve also supervised two post-doctoral fellows (K.-J. Ahn and V. Gusarov). Steve served as secondary advisor for dozens of other students at the University of Kansas. He had four students currently working on M.Sc. or Ph.D. degrees (S. Davis, M.-L. Jeng, M. Rightmyer, and J. Thomas). His involvement with students was not limited to Staphylinidae but included numerous other families and through his strong interest in beetle evolution and natural history, he trained his students to be fully cognizant of the principles and methods of modern systematics.

To all of us, Steve was the person who offered logic to quell strong debate within a group. He was a person who did not share in off-color jokes and did not engage in harsh or profane language. And, if you confided in him, he was a trusted person who would offer guidance or advice to help you through a difficult time. All of this he did quietly and thoughtfully.

Steve was born on February 23, 1947 in Charlotte, North Carolina, and like most of the coleopterists who knew him, he was very interested in natural history as a youngster. The Staphylinidae later became the vehicle for Steve to exploit his passions in his professional career. He sometimes lamented that staphylinids were so poorly known that he needed to spend his time working on systematic problems rather than researching the natural history that he found even more interesting. Steve loved fieldwork. In the mid 1970's, before transfering to the University of Alberta with George Ball, Steve made his first trip into the Neotropics, traveling to Oaxaca and Chiapas, Mexico with Horace Burke and Joe Schaffner, among others. On that trip he got so sick that when he stopped collecting and set up his cot in order to recover, he noticed that vultures started to congregate in the trees above him! When Steve returned there with George Ball in 1979, he reminisced about his surreal experience.

In 1986, Steve made his first trip south beyond Mexico, joining Bob Timm in Costa Rica. Their primary goal was to study the ecology and systematics of amblyopinine beetles and their rodent hosts (they eventually made three such trips). Steve was terribly anxious to experience the true tropics first-hand, and he thrived on the rigors of fieldwork and the diversity he encountered. Their trip was highly productive and eyeopening. Many discoveries were made, not only of mammal host symbiosis, but other complex relationships of inquilines, myrmecophiles, and termitophiles, as well (see Ashe \& Timm 1986a-b, 1987a-c; Timm \& Ashe 1987). Their last day of fieldwork on the amblyopinines in Monteverde was celebrated by hauling wine, Monteverde cheese, and homemade bread up the trail for a mountaintop picnic. Steve wanted to celebrate their first successful expedition properly!

On the second amblyopinine trip to Costa Rica, Steve made a really remarkable discovery. He became curious about working out the association of the aleocharine genus Tachiona with the webs of hepialid moths at Monteverde. He discovered that the 


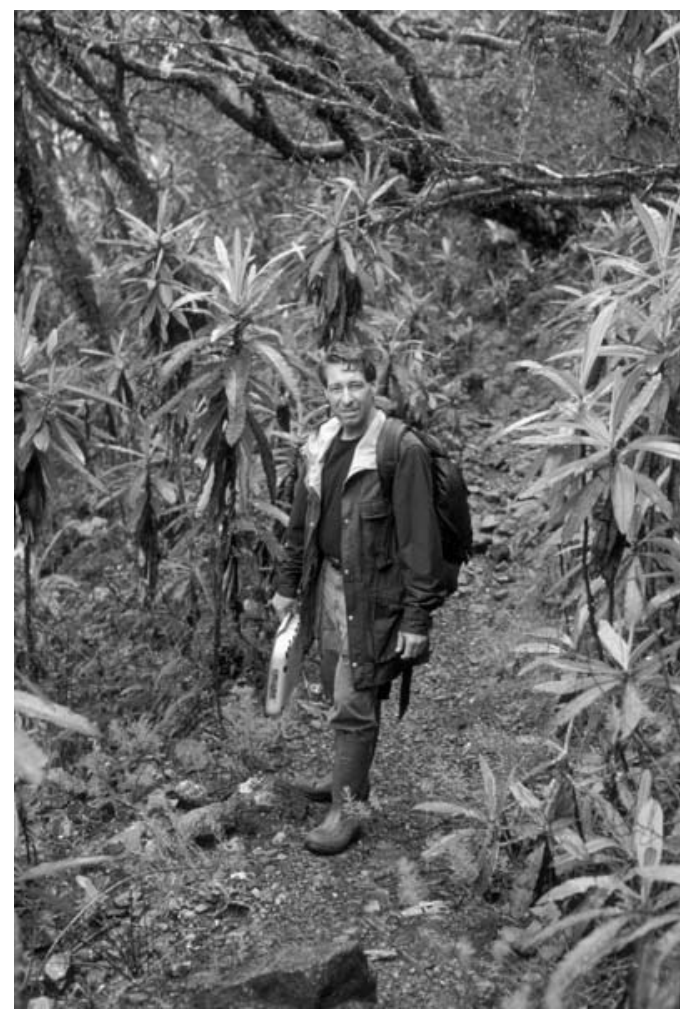

Steve Ashe in Laguna Negra, Venezuela, 1998 (photo by Bob Anderson).

beetles, which were considered extremely rare at the time, were found abundantly inside the webs that covered the ghost moth burrows and were found only on trunks of trees of the genus Trema (Ashe 1990). His discoveries were a combination of firstrate field observations and unrelenting detective work that characterized all of his expeditions.

Steve was highly driven and focused, both in the office and in the field. When Steve was in town, most students do not remember him missing a day of work. He also worked most Saturdays for at least half a day. Steve was a keystone to the Snow Museum. His work ethic carried over into his fieldwork as well. In 1994, Steve happened to be in Honduras with Bob Anderson and Rob Brooks at a small hotel in the coastal town of Tela when the infamous O. J. Simpson white bronco pursuit was live on every TV channel! With everyone around glued to this absurd scene and interested in the developing situation, Steve just wondered if the weather would hold off so they would be able to get out to do some night collecting! This was vintage Steve.

Traveling with Steve in the field gave us some special glimpses of his character when he would spontaneously reminisce about another trip, or effuse over a discovery of the day. One example of this was in Coatepec, Mexico, in 1991. Brett Ratcliffe, Mary Liz Jameson, and Miguel Morón escaped with Steve from the rain into an open-air eatery. As the rain began to pound harder on the roof and the smell of dobladas emanated from 


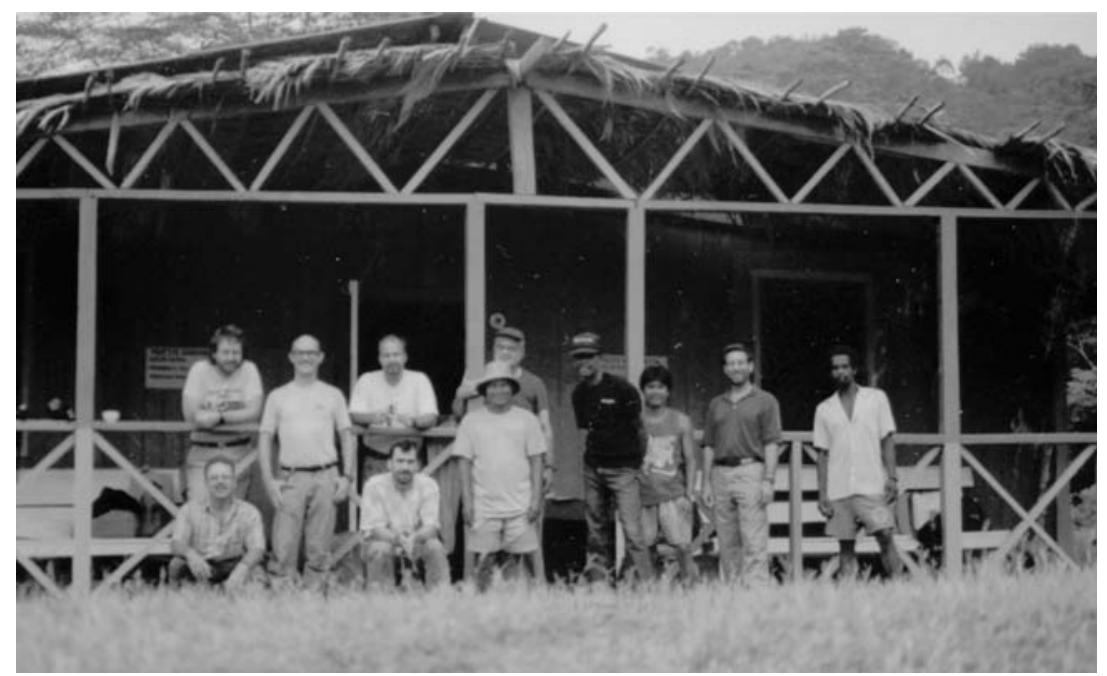

Cana Field Station, Darién, Panama, 1996. Steve Ashe standing second from right. Also, from middle to left, Henry Stockwell (rear), Rob Brooks (rear), Steve Lingafelter (front), Al Gillogly (standing), Bob Anderson (rear) and Don Windsor (front).

the greasy grill, Steve relaxed into his chair, slowly imbibed a beer, and beamed about the staphylinids he had collected that day from isolated pockets of leaf litter and fungi. He told stories about collecting with George Ball on an early trip to Chiapas and laughed deeply about their timely escape from the pouring rain.

Another example was on the trip to the Darién region of Panama trip in 1996. A temporary camp had been set up in the cloud forest on Cerro Pirre and the large group of coleopterists (including Bob Anderson, Rob Brooks, Al Gillogly, Steve Lingafelter, Henry Stockwell, and Don Windsor) took turns hiking up in twos and threes as there was limited tent space at the higher elevation. Steve and his hiking partners were determined to get an early start on their allotted day. That morning, Steve was leading the way up the trail. He was very fit and a strong hiker and soon left the others trailing behind. On the upper trail, people noticed footprints of a large mammal. When Steve met the rest of the group later in the day, he shared his excitement at observing for some time a jaguar, the source of the footprints! It is extremely rare to encounter these in the wild, and he recounted his fortunate experience with unbridled excitement.

After the Darién leg of this same 1996 Panama trip, Steve met Ratibor Hartmann, owner of the famous coffee farm in Panama, just across the border from Costa Rica. Over drinks one evening, Mr. Hartmann described to Steve a somewhat mythical, isolated valley high in the mountains of Costa Rica, dominated by majestic oak trees, festooned with epiphytes, divided by a river flowing quietly through the forest. It was very difficult to access, requiring a guide and hours of hiking, but it sounded like a biologist's Shangri La. The name of the place was Valle de Silencio and for the next few years Steve talked frequently and enthusiastically about getting there. Just a few months ago, Steve was forwarded some staphylinids by Bob Anderson who finally had a chance to visit this locality. Steve was ecstatic to see the material and eagerly talked of making the trip. Hard work in the field was no obstacle to Steve and he would often hike for many hours to access special places. Steve confessed that he wanted to get in as much of this 'difficult' field work as he could while he was still young, fit and able and 
would save the cushy 'La Selva Biology Station type' work for when he was older and less able to get around. Alas, he did not get that opportunity.

Steve was always concerned about the safety and security of his partners on field expeditions so on the 2000 Costa Rica trip, walky-talkies were employed to keep tabs on the team members-and boast about what exciting captures were being made. On that trip, Zack Falin communicated to Steve that he had just taken a single specimen of Bolitogyrus (an ostensibly rare, higher elevation staphylinine) in a location near San Gerardo de Dota, on the Pacific side of Cerro de la Muerte. Four years later, Steve and Zack again found themselves at this locality. Steve remembered vividly how he had not taken Bolitogyrus on the first trip, and he was determined not to leave the place until he succeeded in capturing a specimen. There were no cans of Raid (invaluable for extracting fungus beetles) or unmolested fungi-laden logs left, but Steve did get a specimen in 2004 (as did Zack), and afterwards they both celebrated with beers.

Steve spent nearly two years of his career (over 30 trips during the period 19742005) doing fieldwork in the U.S. and in 10 other countries in the Neotropics. In addition, he recently spent nearly a year on sabbatical in Australia. These expeditions were the foundation for Steve's important natural history collections and publication legacy and were an integral part of his professional life.

While at the University of Kansas, Steve nearly tripled the size of the collections (less than 2 million specimens when he arrived to over 4.5 million specimens in 2005) through his tireless Staphylinidae expeditions in the Neotropics. Most of these trips are listed on the University of Kansas website: http://www.nhm.ku.edu/ksem/features/ expeditions.html. Steve developed a highly productive and efficient system of employing and training undergraduates to mount the huge number of specimens collected in his flight intercept traps. Each student would point hundreds of beetles each day, and thus Steve avoided (or at least tempered) a major problem plaguing most museums, that of an overwhelming backlog of unprepared material. Worldwide, many researchers in other beetle families can attest to the valuable material collected, prepared, and disseminated from the Snow Museum resulting from Steve's expeditions. Thus, the impact Steve had in this regard is immeasurable.

At the University of Kansas, Steve continued the remarkable grantsmanship he started while at the Field Museum. It is astonishing to realize that Steve, in his short career, wrote successful grant proposals for nearly $\$ 3$ million-unheard of in systematics. He received two National Science Foundation PEET grants while at KU, and was among the first to receive such grants. This allowed for his impressive student training program and resulted in opening up the coleopterological "black hole" of the Aleocharinae. Because of the resources Steve acquired combined with his enthusiasm, this subfamily is now accessible and is being studied by a team of researchers in many different countries.

Steve placed a high value on making collections accessible to the world community. He made a commitment to specimen-level databasing, and led the charge by creating over 630,000 database records from the KU collections with his team of collection managers and other staff. This may be on of the largest entomological databases in existence, and had been an intense labor for ten years.

Steve made an important contribution to the education of undergraduate and graduate students. In 2001, Steve received the Kemper Fellowship of Teaching Excellence, one of the highest awards at the University of Kansas. While spontaneous conversation didn't come easily to Steve, he worked extremely hard at preparing the subject matter for his lectures in exhaustive detail. His lectures were immaculately organized and thorough. In all his lectures and scientific presentations, audiences knew immediately of Steve's high standards of excellence. This was evident in the last scientific presentation Steve gave (at the Entomological Society of America meetings in December, 
2005). Steve always synthesized complex concepts exceedingly well, and clearly articulated the pros and cons of theories in a balanced and unbiased manner. He provided the data for his audience to arrive at their own conclusion regarding the validity of an idea. He often tested his students in this way, forcing them to articulate their positions on various theories or concepts to be sure they understood the methods and underlying principles and not just the answer.

Steve made a great impact in his career through his generous service to societies in many capacities and his service on various review committees and panels. Steve served as a Scientific Editor for two journals for a total of 6 years (Fieldiana \& Thomas Say Monographs of the Entomological Society of America). Steve served as Section A Secretary and Chairman for the Entomological Society of America. Steve was President of the Coleopterists Society in 1990-1991. In the last few years, Steve was called on to serve on various panels to review and evaluate entomological departments at several universities. Steve was a member of the following societies at the time of his death: American Association for the Advancement of Science, The Coleopterists Society, Society of Systematic Biology, Entomological Society of America, Kansas Entomological Society, New York Academy of Sciences, New York Entomological Society, Society for the Study of Evolution and Sigma Xi.

One of the greatest signs of respect that can be shown for our colleagues is to name species in their honor. Steve had 25 species patronyms, mostly in Coleoptera (spanning 6 families), but also two in Hymenoptera. Undoubtedly, there will be many more over the coming years. Many are based on specimens that Steve collected. These patronyms are listed chronologically below:

Oxyporus ashei Campbell 1978 (Coleoptera: Staphylinidae)

Lordithon ashei Campbell 1982 (Coleoptera: Staphylinidae)

Pterostichus ashei Ball \& Roughly 1982 (Coleoptera: Carabidae)

Coenonica ashei Pace 1988 (Coleoptera: Staphylinidae)

Ischnosoma ashei Campbell 1991 (Coleoptera: Staphylinidae)

Labidopullus ashei Jacobson \& Kistner 1991 (Coleoptera: Staphylinidae)

Megalopinus ashei Puthz 1994 (Coleoptera: Staphylinidae)

Ontherus ashei Génier 1996 (Coleoptera: Scarabaeidae)

Megarthrus ashei Cuccodoro \& Löbl 1996 (Coleoptera: Staphylinidae)

Ecitoxenidia ashei Kistner 1996 (Coleoptera: Staphylinidae)

Corticarina ashei Johnson 1997 (Coleoptera: Latridiidae)

Tagmalycra ashei Kirejtshuk \& Leschen 1998 (Coleoptera: Nitidulidae)

Tetradonia ashei Jacobson \& Kistner 1998 (Coleoptera: Staphylinidae)

Dryinus ashei Olmi 1998 (Hymenoptera: Dryinidae)

Aleochara ashei Maus 2000 (Coleoptera: Staphylinidae)

Bdelyrus ashei Cook 2000 (Coleoptera: Scarabaeidae)

Phloeoxena ashei Ball \& Shpeley 2000 (Coleoptera: Carabidae)

Lispinus ashei Irmler 2001 (Coleoptera: Staphylinidae)

Edaphus ashei Puthz 2001 (Coleoptera: Staphylinidae)

Deinodryinus ashei Olmi 2001 (Hymenoptera: Dryinidae)

Anaulacus ashei Ball \& Shpeley 2002 (Coleoptera: Carabidae)

Leptandria ashei Hanley 2003 (Coleoptera: Staphylinidae)

Chelonarhister ashei Dégallier 2004 (Coleoptera: Histeridae)

Holotrochus ashei Irmler 2005 (Coleoptera: Staphylinidae)

Scaphidium ashei Fierros-López 2005 (Coleoptera: Staphylinidae)

Of course, the most lasting legacy of Steve's contribution to entomology is his voluminous scientific publication record. During the period 1973-2005, Steve published over 100 mostly peer-reviewed papers, including many large monographs, and numerous web pages for the Tree of Life and other projects. These are listed below in chronological order. Perusing this impressive list of publications allows one to quickly 
see the breadth of knowledge Steve possessed in Staphylinidae, and demonstrates his world class standing as a preeminent researcher in this group of beetles. In total, Steve described at least 103 new species and 17 new genera in these papers. Steve was a strong proponent of the use of the internet for the dissemination of research results and loved the fact that one could post numerous photographs at little expense, a limiting factor in traditional paper publications. He was always actively exploring new ways to make scientific information increasingly accessible to the public, and many examples can be seen at the University of Kansas website.

Steve was a very generous researcher as evidenced by the high number of collaborations in which he engaged. Approximately half of his research publications involved one or more coauthors, totaling over 20 different individuals. These collaborations resulted in many seminal papers. For example, his 1984 larval chaetotaxy paper with Watrous is still being used as a model for larval descriptions in Staphylinoidea.

Although Steve's life was cut short, he lived it with endless curiosity about the natural world, with great joy, enthusiasm and excitement at even the smallest of new discoveries. He partook of innumerable experiences that most people never have. While we mourn his loss, Steve's influence on his colleagues and students and his scientific legacy will always be a part of us and our science.

Steve spoke extensively about his wife Aagje and son Thomas with many of his friends and colleagues, and they accompanied him on some of his field trips. The Coleopterist community extends deepest sympathies to them for their loss. We dedicate this issue of The Coleopterists Bulletin to Steve's memory.

Steve Lingafelter, Bob Anderson, Bob Timm, Zack Falin, Mary Liz Jameson, Al Newton, George Ball, Kee-Jeong Ahn \& Rich Leschen

Additional details of Steve's life and career are included in Timm, R. M. 2006. In Memoriam: James S. "Steve" Ashe, 1947-2005. Journal of the Kansas Entomological Society, 79.

\section{Publications by J. Steve Ashe (in chronological order)}

Ashe, J. S., and J. F. Cornell. 1973. Some aspects of the host-fungus relationships of beetles of the subtribe Gyrophaenae (Staphylinidae: Aleocharinae). Journal of the Elisha Mitchell Society 89(4):249 (Abstract).

Ashe, J. S. 1980. The gyrophaenines (Staphylinidae: Aleocharinae), a group of obligatory mushroom-inhabiting rove beetles: the mushroom as a habitat. Proceedings of the Entomological Society of Alberta 27:14 (Abstract).

Ashe, J. S. 1981. Studies of the life history and habits of Phanerota fasciata (Say) (Coleoptera: Staphylinidae: Aleocharinae) with notes on the mushroom as a habitat and descriptions of the immature stages. The Coleopterists Bulletin 35(1):83-96.

Ashe, J. S. 1982 (1981). Construction of pupal cells by larvae of Aleocharinae (Coleoptera: Staphylinidae). The Coleopterists Bulletin 35(3):341-343.

Ashe, J. S. 1982. Evidence about species status of Phanerota fasciata (Say) and Phanerota dissimilis (Erichson) (Coleoptera: Staphylinidae: Aleocharinae) from host mushroom relationships. The Coleopterists Bulletin 36(2):155-161.

Ashe, J. S. 1984. Major features of the evolution of relationships between gyrophaenine staphylinid beetles (Coleoptera: Staphylinidae: Aleocharinae) and fresh mushrooms [pp. 227-255]. In: Fungus/Insect relationships: perspectives in ecology and evolution (Q. Wheeler and M. Blackwell, editors). Columbia University Press.

Ashe, J. S. 1984. Generic revision of the subtribe Gyrophaenina (Coleoptera: Staphylinidae: Aleocharinae) with review of the described subgenera and major features of evolution. Questiones Entomologicae 20:129-349. 
Ashe, J. S. 1984. Evolution of mushroom feeding in gyrophaenine staphylinid beetles (Coleoptera: Staphylinidae: Aleocharinae). XVII International Congress of Entomology (Abstract).

Ashe, J. S. 1984. Description of the larva and pupa of Scaphisoma terminata Melsh and the larva of Scaphium castanipes Kirby (Scaphidiidae) with notes on their natural history (Coleoptera: Scaphidiidae). The Coleopterists Bulletin 34(4):361-373.

Ashe, J. S., and L. E. Watrous. 1984. Larval chaetotaxy of Aleocharinae (Staphylinidae) based on a description of Atheta coriaria Kraatz. The Coleopterists Bulletin 38(2):165-179.

Ashe, J. S. 1985. Fecundity, development and natural history of Meronera venustula (Erichson) (Coleoptera: Staphylinidae: Aleocharinae). Psyche 92(2-3):181-204.

Ashe, J. S. 1986. Phanerota cubensis and Phanerota brunnessa $\mathrm{n}$. sp. with a key to the species of Phanerota occurring in Florida (Coleoptera: Staphylinidae). Florida Entomologist 69(1):236-245.

Ashe, J. S. 1986. Structural features and phylogenetic relationships among larvae of genera of gyrophaenine staphylinids (Coleoptera: Staphylinidae: Aleocharinae). Fieldiana: Zoology (New Series) 30:1-60.

Ashe, J. S. 1986. Seeversiella bispinosa, a new genus and species of athetine Aleocharinae (Coleoptera: Staphylinidae) from North America. Journal of the New York Entomological Society, 94(4):500-511.

Ashe, J. S. 1986. Subsocial behavior among gyrophaenine staphylinids. Sociobiology 12(2): 315-320.

Ashe, J. S., and R. M. Timm. 1986a. Mammals and beetles in Costa Rica. Field Museum of Natural History Bulletin 57(10):11-18.

Ashe, J. S., and R. M. Timm. 1986b. Host and elevational specificity of parasitic beetles (Amblyopinus) on neotropical mammals. American Society of Mammalogists (Abstract).

Ashe, J. S. 1987. Egg chamber production, egg protection and clutch size among fungivorus beetles of the genus Eumicrota (Coleoptera: Staphylinidae) and their evolutionary implications. Zoological Journal of the Linnean Society 90(3):255-273.

Ashe, J. S., and R. M. Timm. 1987a. Predation by and activity patterns of "parasitic" beetles of the genus Amblyopinus (Coleoptera: Staphylinidae). Journal of Zoology (London) 212(3):429-437.

Ashe, J. S., and R. M. Timm. 1987b. Probable mutualistic association between staphylinid beetles (Amblyopinus) and their rodent hosts. Journal of Tropical Ecology 3(2):177-182.

Ashe, J. S., and R. M. Timm. 1987c. Evolution of the interaction between staphylinid beetles (Amblyopinus) and their rodent hosts. American Society of Mammalogists (Abstract).

Timm, R. M., and J. S. Ashe. 1987. Host and elevational specificity of parasitic beetles (Amblyopinus Solsky) (Coleoptera: Staphylinidae) in Panama. Proceedings of the Biological Society of Washington 100(1):13-20.

Ashe, J. S. 1988. Book Review: Arnett, R. H. and G. A. Samuelson. 1986. The insect and spider collections of the world. Flora and Fauna Publs., Gainesville, FL. 220 pp. Collections Forum 4(1): 19-20.

Ashe, J. S., and H. Marx. 1988. Phylogeny of the viperine snakes (Viperinae): Part II. Cladistic analysis and major lineages. Fieldiana: Zoology (New Series) 52:1-23.

Ashe, J. S., and R. M. Timm. 1988. Chilamblyopinus piceus, a new genus and species of amblyopinine (Coleoptera: Staphylinidae) from southern Chile, with a discussion of amblyopinine generic relationships. Journal of the Kansas Entomological Society 6(1):46-57.

Ashe, J. S., and Q. D. Wheeler. 1988. Revision of Tachiona Sharp (Coleoptera: Staphylinidae: Aleocharinae) with a description of the larva of $T$. latipennis new species, and a preliminary assessment of generic relationships. Journal of the New York Entomological Society 96(2):176-199.

Marx, H., J. S. Ashe, and L. E. Watrous. 1988. Phylogeny of the viperine snakes (Viperinae): Part I. Character analysis. Fieldiana: Zoology (New Series) 51:1-16.

Timm, R. M., and J. S. Ashe. 1988. The mystery of the gracious hosts. Natural History Magazine 9/88:6-10.

Abarbanell, N. R., and J. S. Ashe. 1989. Revision of the species of Pinophilus Gravenhorst (Coleoptera: Staphylinidae) of America north of Mexico. Fieldiana: Zoology (New Series) 54:1-32. 
Ashe, J. S., and D. H. Kistner. 1989. Larvae and adults of a new species of Euvira (Coleoptera: Staphylinidae: Aleocharinae) from the nests of the communal pierid butterfly Eucheira socialis with a redescription of the genus Euvira. Sociobiology 15(1):85-106.

Timm, R. M. and J. S. Ashe. 1989. The probable larva of an undescribed species of Edrabius (Coleoptera: Staphylinidae) and its implications for the systematics of the tribe Amblyopinini. Journal of the Kansas Entomological Society 62(3):374-380.

Ashe, J. S. 1990. Natural history, development and immatures of Pleurotobia tristigmata (Erichson) (Coleoptera: Staphylinidae: Aleocharinae). The Coleopterists Bulletin 44(4):445-460.

Ashe, J. S. 1990. Book Review: Nichols, S. W. (compiler) and R. T. Schuh (editor). 1989. The Torre-Bueno Glossary of Entomology. Revised Edition, including Supplement A by G. S. Tulloch. New York Entomological Society, N.Y. 840 pp. Recent Publications in Natural History 8(2):5-7.

Ashe, J. S. 1990. New species, phylogeny and natural history of Tachiona Sharp 1883 (Coleoptera: Staphylinidae: Aleocharinae). Tropical Zoology 3(2):225-235.

Ashe, J. S. 1991 (1990). The larvae of Placusa Mannerhein (Coleoptera: Staphylinidae), with notes on their feeding habits. Entomologica Scandinavica 21:477-485.

Ashe, J. S. 1991. Technical Report: A resource management report: Snow Entomological Museum participation in-Bolivian Expedition BIOLAT SI/MAB - 1988: Report on costs in time and materials. Insect Collection News 6:15-16.

Ashe, J. S. 1991. Males of Tachiona deplanata Sharp and T. nitida Ashe (Coleoptera: Staphylinidae) with notes on the habitat of these species. Journal of the New York Entomological Society 99(2):248-250.

Ashe, J. S. 1991. The systematic position of Placusa Erichson and Euvira Sharp: the tribe Placusini described (Coleoptera: Staphylinidae: Aleocharinae). Systematic Entomology 16:383-400.

Ashe, J. S., and S. J. Weller. 1991. Technical Report: ECN discussion group summary: Summary report of ECN Workshop: Interactions of science and service. Insect Collection News 6:4-5.

Klimaszewski, J., and J. S. Ashe. 1991. The oxypodine genus Haploglossa Kraatz in North America (Coleoptera: Staphylinidae: Aleocharinae). Giornale Italiano di Entomologia 5:409-416.

Ahn, K.-J., and J. S. Ashe. 1992. Revision of the intertidal aleocharine genus Pontomalota Casey (Coleoptera: Staphylinidae) with a discussion of its phylogenetic relationships. Entomologica Scandinavica 23:347-359.

Ashe, J. S. 1992. Phylogeny and revision of genera of the subtribe Bolitocharina (Coleoptera: Staphylinidae: Aleocharinae). University of Kansas Science Bulletin 54(10):335-406.

Ashe, J. S. 1992. Popular Article: Insight, Pew Charitable Trusts. Panorama 21(2):6.

Klimaszewski, J., and J. S. Ashe. 1992. Aleochara Gravenhorst (Coleoptera: Staphylinidae: Aleocharinae) of the Monteverde Region of Costa Rica. Annals of the Transvaal Museum 35(28):399-410.

Klimaszewski, J., and J. S. Ashe. 1993 (1992). Two new species of the myllaenine genus Pseudomniophila Pace from the montane forests of Costa Rica (Coleoptera: Staphylinidae: Aleocharinae). Elytron 6:77-85.

Ashe, J. S. 1993. Mouthpart modifications correlated with fungivory among aleocharine staphylinids (Coleoptera: Staphylinidae: Aleocharinae) [pp. 105-130]. In: Symp. Funct. Morph. Insect Mouthparts (C. W. Schaefer and R. Leschen, editors). Thomas Say Publications in Entomology, Entomological Society of America, Lanham, MD.

Ashe, J. S. 1993. New species and records of Tachiona Sharp (Coleoptera: Staphylinidae, Aleocharinae) with a revised key to known species. Entomologica Scandinavica 24: 231-239.

Ashe, J. S. 1993. Sampling rove beetle (family Staphylinidae) biodiversity at Las Cruces. OTS Amigos Newsletter 38:12-15.

Ashe, J. S., and A. F. Newton, Jr. 1993. Larvae of Trichophya and phylogeny of the tachyporine group of subfamilies (Coleoptera: Staphylinidae) with a review, new species and characterization of the Trichophyinae. Systematic Entomology 18:267-286.

Ashe, J. S. 1994. Evolution of aedeagal parameres of aleocharine staphylinids (Coleoptera: Staphylinidae: Aleocharinae). Canadian Entomologist 126:475-491. 
Hoebeke, E. R., and J. S. Ashe. 1994. New species of Autalia Leach 1819 from the Neotropics (Coleoptera Staphylinidae Aleocharinae), with new distributional data for A. phricotrichosa Hoebeke 1988 and key to the Neotropical species of Autalia. Tropical Zoology 7:191-208.

Ahn, K.-J., and J. S. Ashe. 1995. Systematic position of the intertidal genus Bryobiota Casey and a revised phylogeny of the falagriine genera of America north of Mexico (Coleoptera: Staphylinidae: Aleocharinae). Annals of the Entomological Society of America 88(2):143-154.

Ahn, K.-J., and J. S. Ashe. 1996 (1995). Revision of the intertidal aleocharine genus Amblopusa Casey and description of the new genus Paramblopusa (Coleoptera: Staphylinidae). Journal of the New York Entomological Society 103(2):138-154.

Ashe, J. S., and R. A. B. Leschen. 1995. Cajachara carltoni, a new genus and species of rove beetle (Coleoptera Staphylinidae Aleocharinae) from an Ecuadorean paramo. Tropical Zoology 8:85-93.

Ashe, J. S., and S. W. Lingafelter. 1996 (1995). Revision of Gansia Sharp of Mexico and Central America (Coleoptera: Staphylinidae: Aleocharinae). Journal of the New York Entomological Society 103(3):251-280.

Ashe, J. S., and R. M. Timm. 1995. Systematics, distribution, and host specificity of Amblyopinus Solsky 1875 (Coleoptera Staphylinidae) in Mexico and Central America. Tropical Zoology 8:373-399.

Ahn, K.-J., and J. S. Ashe. 1996. Phylogeny of the intertidal aleocharine tribe Liparocephalini (Coleopera: Staphylinidae). Systematic Entomology 21:99-114.

Ahn, K.-J., and J. S. Ashe. 1996. A revision of Rothium Moore and Legner (Coleoptera: Staphylinidae: Aleocharinae) with a discussion of its phylogenetic relationships. Journal of the Kansas Entomological Society 69(3):234-256.

Ashe, J. S., R. M. Timm, and M. H. Gallardo. 1996. Systematics, distribution, and host specificity of Edrabius Fauvel (Coleoptera: Staphylinidae). Proceedings of the Biological Society of Washington 109(4):731-743.

Kistner, D. H., J. S. Ashe, and H. R. Jacobson. 1996. New species of the myrmecophilous genera Microdonia, and Ecitoxenidia from Mexico (Coleoptera, Staphylinidae) with a review of previously described species. Sociobiology 27(1):47-78.

Hanley, R. S., and J. S. Ashe. 1998. A new genus and species of aleocharine rove beetle (Coleoptera Staphylinidae Aleocharinae Hoplandriini) from the New World. Tropical Zoology 11:183-191.

Ahn, K.-J., and J. S. Ashe. 1999. Two new species of Amazonopora Pace 1996 (Coleoptera: Staphylinidae: Aleocharinae) from Peru and French Guiana with a discussion of its phylogenetic relationships. Tropical Zoology 12(1):125-136.

Ahn, K.-J., and J. S. Ashe. 1999. Two new species of Giulianium Moore from the Pacific Coasts of Alaska and California (Coleoptera: Staphylinidae: Omaliinae). Pacific Insects 75(3):159-164.

Ashe, J. S. 1999. Redescription and phylogenetic position of the unusual aleocharine staphylinid Dimonomera indica Cameron, 1933 (Coleoptera: Staphylinidae: Aleocharinae: Dimonomerini). Journal of the New York Entomological Society 107(1):55-63.

Leschen, R. A. B., and J. S. Ashe. 1999. New species, phylogenetic placement and mammal associations of Loberopsyllus (Languriidae: Xenoscelinae). University of Kansas Natural History Museum Special Publication 24:171-177.

Anderson, R. S., and J. S. Ashe. 2000. Leaf litter inhabiting beetles as surrogates for establishing priorities for conservation of selected tropical montane cloud forests in Honduras, Central America (Coleoptera; Staphylinidae, Curculionidae). Biodiversity and Conservation 9:617-653.

Ashe, J. S. 2000. Mouthpart structure of Stylogymnusa subantarctica Hammond, 1975 (Coleoptera: Staphylinidae: Aleocharinae) with a reanalysis of the phylogenetic position of the genus. Zoological Journal of the Linnean Society 130(4):471-498.

Ashe, J. S. 2000. Rove beetles (Staphylinidae) of Monteverde [pp. 108-111]. In: The natural history and ecology of Monteverde, Costa Rica: a background to conservation (N. Nadkarni and N. T. Wheelwright, editors). Oxford University Press, New York.

Ashe, J. S. 2001. Aleocharinae, Staphylinidae Latreille, 1802 [pp. 295-324, 358-375, 397-418]. In: A. F. Newton, M. K. Thayer, J. S. Ashe, and D. S. Chandler. Staphylinidae [pp. 272- 
418]. In: American Beetles: Vol. 1, Archostemata, Myxophaga, Adephaga, Polyphaga: Staphyliniformia (R. Arnett and M. Thomas, editors). CRC Press LLC, Boca Raton. Xv + $1-443 \mathrm{pp}$.

Ashe, J. S. 2002. Allodinopsis, a new genus of deinopsine aleocharine from Central America, and a new species of Metadeinopsis Klimaszewski 1979 (Staphylinidae, Aleocharinae, Deinopsini). Journal of the Kansas Entomological Society 75(2):61-72.

Ashe, J. S. 2002. Aleocharinae [pp. 121-199]. In: Guía illustrada para los géneros de Staphylinidae (Coleoptera) de México (A. F. Newton, Jr., J. L. Navarrette, J. S. Ashe, and D. Chandler, editors). CONABIO, Universidad de Guadalajara. 401 pp.

Ashe, J. S. 2002. The Aleocharinae (Coleoptera: Staphylinidae) of Australia. Bioloque, Australian Biological Resources Study 26:13.

Hanley, R. S., and J. S. Ashe. 2003. Techniques for dissecting adult Aleocharine beetles (Coleoptera). Bulletin of Entomological Research 93:11-18.

Ashe, J. S., and S. Chatzimanolis. 2003. A revision of the genus Elmas Blackwelder, 1952 (Coleoptera: Staphylinidae: Staphylininae), with a preliminary reconstructed phylogeny of the species. Scientific Papers of the Natural History Museum, University of Kansas. 28:1-41.

Ashe, J. S., and V. Gusarov. 2003. Review of Anatheta Casey, 1910 (Staphylinidae: Aleocharinae: Athetini), with notes on synonymy of Canastota Casey, 1910 and Silusida Casey, 1906. The Coleopterists Bulletin 57(1):27-36.

Ashe, J. S. 2003. Weiria australis new genus new species, the first fully myrmecoid aleocharine staphylinid from Australia (Coleoptera: Staphylinidae: Aleocharinae: Aenictoteratini). Australian Journal of Entomology 42:179-184.

Ashe, J. S. 2003. First record and four new species of Adelarthra Cameron 1920 from Australia, and a related new genus and species Notiomerinx zealandica n. gen, n. sp., from New Zealand (Coleoptera: Staphylinidae: Aleocharinae). In: Systematics of Coleoptera: Papers Celebrating the Retirement of Ivan Löbl (G. Cuccodoro and R. A. B. Leschen, editors). Memoirs on Entomology, International 17:617-626.

Ashe, J. S. 2004. A distinctive new species of the myrmecophilous genus Dentaphila Kistner 1997, and the first record of the genus from Australia (Coleoptera: Staphylinidae: Aleocharinae). Journal of the Kansas Entomological Society 77(1):45-50.

Chatzimanolis, S., and J. S. Ashe. 2004. On the identity of Plociopterus variegatus Sharp (Coleoptera: Staphylinidae). The Coleopterists Bulletin 58(1):53-55.

Thayer, M., J. S. Ashe, and R. S. Hanley. 2004. Discovery of the remarkable larvae of Hoplandriini (Coleoptera: Staphylinidae: Aleocharinae). Annals of the Entomological Society of America 97(4):624-634.

Ashe, J. S., and V. Gusarov. 2004. Review of the genus Sableta Casey 1910 (Coleoptera: Staphylinidae: Aleocharinae). Zootaxa 745:1-15.

Ahn, K.-J., and J. S. Ashe. 2004. Phylogeny of the Myllaenini and related taxa (Coleoptera: Staphylinidae: Aleocharinae). Cladistics 20:123-138.

Ashe, J. S. 2005. Three new genera and four new species of aleocharine staphylinids with unusually long mandibles from Australia (Coleoptera: Staphylinidae: Aleocharinae: Homalotini). Zootaxa 1002:21-44.

Ashe, J. S. 2005. Phylogeny of the tachyporine group subfamilies and "basal" lineages of the Aleocharinae (Coleoptera: Staphylinidae) based on larval and adult characteristics. Systematic Entomology 30:3-37.

Ashe, J. S. 2005 (2004). A new species of the intertidal staphylinid genus Bryothinusa Casey from Malaysia, with an overview of geographic distribution and an annotated catalog of Bryothinusa (Staphylinidae: Aleocharinae: Myllaenini). The Coleopterists Bulletin 58(4):581-597.

Ashe, J. S., and K.-J. Ahn. 2005 (2004). Paradiglotta nunni, a remarkable new genus and species in the Aleocharinae tribe Diglottini (Coleoptera: Staphylinidae: Aleocharinae) from New Zealand. Journal of the New York Entomological Society 112:111-120.

Ashe, J. S., and D. H. Kistner. 2005. Revision of the myrmecophilous genus Myrmigaster, with new synonymy and descriptions of new species (Coleoptera: Staphylinidae: Aleocharinae). Sociobiology 45(2):221-254.

Chatzimanolis, S., J. S. Ashe, and R. S. Hanley. 2005 (2004). Diurnal/nocturnal activity of 
rove beetles (Coleoptera: Staphylinidae) on Barro Colorado Island, Panama assayed by flight intercept trap. The Coleopterists Bulletin 58(4):569-577.

Chatzimanolis, S., and J. S. Ashe. 2005. Revision and phylogeny of the Neotropical genus Philothalpus Kraatz, (= Eugastus Sharp and Allostenopsis Bernhauer) (Coleoptera: Staphylinidae: Xanthopygina). Insect Systematics and Evolution 36:63-119.

Cornell, J. F., and J. S. Ashe. 2006. New Coleoptera records for North Carolina. The Coleopterists Bulletin 59(4):506.

Ashe, J. S., and S. Chatzimanolis. 2006. Three new species and new records of Elmas (Coleoptera: Staphylinidae: Xanthopygina) from South America with a reanalysis of the phylogenetic relationships among the species of Elmas. Annals of the Entomological Society of America 99(1):19-32.

\section{World Wide Web Publications by J. Steve Ashe (in chronological order)}

Ashe, J. S. 1998. Overview of described Mexican genera of the staphylinid subfamily Aleocharinae. http://nhm.ku.edu/ksem/peet/catalogs/aleogen.htm

Ashe, J. S. 1998. Subfamily Aleocharinae. In: The tree of life: a distributed internet resource containing information about phylogeny and biodiversity (D. R. Maddison and W. P. Maddison, editors). http: //tolweb.org/tree?group $=$ Aleocharinae \&contgroup $=$ Staphylinidae\# Introduction

Chatzimanolis, S., and J. S. Ashe. 2003. Genus Elmas and containing group Xanthopygina. In: The tree of life: a distributed internet resource containing information about phylogeny and biodiversity (D. R. Maddison, editor). http://tolweb.org/tree?group=Elmas\& contgroup $=$ Xanthopygina.

Ashe, J. S., and S. Chatzimanolis. 2003. Tribe Gymnusini. In: The tree of life: a distributed internet resource containing information about phylogeny and biodiversity (D. R. Maddison, editor). http://tolweb.org/tree?group=Gymnusini\&contgroup=Aleocharinae.

Ashe, J. S., and S. Chatzimanolis. 2003. Tribe Deinopsini. In: The tree of life: a distributed internet resource containing information about phylogeny and biodiversity (D. R. Maddison, editor). http://tolweb.org/tree?group=Deinopsini\&contgroup=Aleocharinae.

Ashe, J. S. 2005. Family Staphylinidae (Coleoptera), at: http://www.uky.edu/cgi-bin/cgiwrap/ mjshar0/taxa.cgi?family=Staphylinidae. In: Sharkey, M. J. Colombian Species Database, at: http://www.uky.edu/ mjshar0/colombia/en-database.html.

(Received and accepted 2 February 2006) 